\title{
Stimulus-dependent Secretion of Plasma Proteins from Human Neutrophils
}

\author{
Niels Borregaard, Lars Kjeldsen, Kåre Rygaard, * Lone Bastholm, * Morten H. Nielsen, * Henrik Sengelov, \\ Ole W. Bjerrum, and Anders H. Johnsen" \\ Granulocyte Research Laboratory, Department of Medicine and Hematology L-4042, University Hospital, *University Institute \\ of Pathological Anatomy, ${ }^{\ddagger}$ Department of Clinical Chemistry, University Hospital, DK-2100 Copenhagen, Denmark
}

\begin{abstract}
In search for matrix proteins released from secretory vesicles of human neutrophils, a prominent $67-\mathrm{kD}$ protein was identified in the extracellular medium of neutrophils stimulated by the chemotactic peptide, FMLP. The protein was purified to apparent homogeneity and partially sequenced. The sequence of the first $32 \mathrm{NH}_{2}$-terminal amino acids was identical to the sequence of albumin. mRNA for human albumin could not be detected in bone marrow cells, nor could biosynthetic labeling of albumin be demonstrated in bone marrow cells during incubation with $\left[{ }^{14} \mathrm{C}\right]$ leucine.

Immunofluorescence studies on single cells demonstrated the presence of intracellular albumin in fixed permeabilized neutrophils. Light microscopy of immunogold-silver-stained cryosections visualized albumin in cytoplasmic "granules." The morphology of these was determined by immunoelectron microscopy as vesicles of varying form and size. Subcellular fractionation studies on unstimulated neutrophils demonstrated the presence of albumin in the low density pre- $\gamma$ and $\boldsymbol{\gamma}$-regions that contain secretory vesicles, but are devoid of specific granules and azurophil granules. Albumin was readily released from these structures during activation of neutrophils with inflammatory mediators. Immunoblotting demonstrated the presence of immunoglobulin and transferrin along with albumin in exocytosed material from stimulated neutrophils. This indicates that secretory vesicles are unique endocytic vesicles that can be triggered to exocytose by inflammatory stimuli. (J. Clin. Invest. 1992. 90:86-96.) Key words: albumin • exocytosis • granules • secretory vesicles • subcellular fractionation
\end{abstract}

\section{Introduction}

Neutrophils are highly specialized cells equipped with a battery of proteolytic and digestive enzymes capable of destroying extracellular matrix and bacterial debris. These enzymes are stored in the matrix of granules of which two kinds have been recognized: the lysosomal-like azurophil granules and the specific granules (1). In addition, the membrane of specific granules contains receptors for chemotactic factors (2), adhesion molecules (3), and elements of the electron transport chain

Address correspondence to Dr. Niels Borregaard, Granulocyte Research Laboratory, Department of Medicine and Hematology L, University Hospital, Rigshospitalet afsnit 4042, Blegdamsvej 9, DK-2100 Copenhagen Ø, Denmark.

Received for publication 6 September 1991 and in revised form 3 January 1992

J. Clin. Invest.

(c) The American Society for Clinical Investigation, Inc.

$0021-9738 / 92 / 07 / 0086 / 11 \$ 2.00$

Volume 90, July 1992, 86-96 functioning as an NADPH oxidase of prime importance for killing of microorganisms $(4,5)$.

Mobilization of granules is an important aspect of neutrophil activation, since this results in recruitment of functional proteins to the plasma membrane and release of destructive enzymes to the environment.

It has been recognized for long that stimulation of neutrophils by inflammatory mediators can result in a severalfold increase in the number of plasma membrane proteins such as complement receptor 3 (6) and decay accelerating factor (7). Yet these stimuli are incapable of mobilizing specific granules to the extent that can explain the upregulation of these proteins in the plasma membrane (8).

A special type of granules identified by their content of gelatinase has been suggested as the source of membrane material readily incorporated into the plasma membrane, since these have been reported to be mobilized more quickly and extensively than specific granules (9). The presence of gelatinase in a separate granule subset has recently been questioned by the demonstration of co-localization of gelatinase and lactoferrin in specific granules using immunoelectron microscopy (10).

We have identified an easily mobilizable intracellular compartment termed secretory vesicles in neutrophils $(8,11)$. These vesicles are identified by their content of alkaline phosphatase that can only be measured in the presence of detergent, in contrast to plasma membrane-bound alkaline phosphatase. These vesicles are readily mobilized to the plasma membrane by stimuli that do not cause significant exocytosis of specific granule content, e.g., nanomolar concentrations of the chemotactic tripeptide FMLP. Mobilization of secretory vesicles is accompanied by release of tetranectin, a protein recently identified in plasma and in all secretory human cells studied (12). Based on their kinetics of mobilization, secretory vesicles qualify as an intracellular store of both cytochrome $b_{558}$ and adhesion proteins $(8,11,13)$.

To further investigate the content of secretory vesicles, we decided to examine the protein profile of material that was exocytosed from neutrophils after stimulation with FMLP. This would permit identification of the most prominent protein (s) released from secretory vesicles, and hopefully give further insight into the origin and function of these structures.

\section{Methods}

Isolation of neutrophils. Peripheral blood was obtained by venipuncture of healthy volunteers, anticoagulated with $25 \mathrm{mM}$ sodium citrate, and mixed at room temperature with an equal volume of $2 \%$ Dextran T-500 (Pharmacia-LKB, Uppsala, Sweden) in $0.9 \% \mathrm{NaCl}$ to ease the sedimentation of erythrocytes. The leukocyte-rich supernatant was centrifuged at $200 \mathrm{~g}$ for $10 \mathrm{~min}$ and the cells resuspended in ice-cold $0.9 \% \mathrm{NaCl}$. Mononuclear cells were separated from polymorphonuclear cells and residual erythrocytes by centrifugation through Lymphoprep (Nyegaard, Oslo, Norway) (14). 
The resulting granulocyte-erythrocyte pellets were resuspended in ice-cold $\mathrm{H}_{2} \mathrm{O}$ for $30 \mathrm{~s}$ to lyse erythrocytes. Isotonicity was subsequently restored with $1.8 \% \mathrm{NaCl}$. Granulocytes were pelleted at $200 \mathrm{~g}$ for 6 min, and resuspended in Krebs-Ringer phosphate: $130 \mathrm{mM} \mathrm{NaCl}, 5$ $\mathrm{mM} \mathrm{KCl}, 1.27 \mathrm{mM} \mathrm{MgSO}_{4}, 0.95 \mathrm{mM} \mathrm{CaCl}_{2}, 5 \mathrm{mM}$ glucose, $10 \mathrm{mM}$ $\mathrm{NaH}_{2} \mathrm{PO}_{4} / \mathrm{Na}_{2} \mathrm{HPO}_{4}, \mathrm{pH} 7.4$.

Isolation of bone marrow cells. $10 \mathrm{ml}$ bone marrow was aspirated under local anesthesia from the superior posterior iliac crest and immediately anticoagulated by adding $100 \mathrm{U} / \mathrm{ml}$ heparin. Mononuclear cells and polymorphonuclear cells were separated by centrifugation on Lymphoprep.

Biosynthesis of albumin in bone marrow cells. $10^{7}$ mononuclear bone marrow cells were resuspended in $2 \mathrm{ml}$ leucine-free minimum essential medium (Eagle) (Gibco Laboratories, Life Technologies Ltd., Grand Island, NY) containing $10 \%$ dialyzed fetal calf serum (Gibco Laboratories) and incubated at $37^{\circ} \mathrm{C}$ for $60 \mathrm{~min}$. This was followed by adding $25 \mu \mathrm{Ci}$ of $\mathrm{L}-\left[{ }^{14} \mathrm{C}\right]$ leucine/ml (NEN DuPont, Boston, MA). After additional $2 \mathrm{~h}$ incubation, the cells were washed twice in saline and resuspended in RIPA buffer: $150 \mathrm{mM} \mathrm{NaCl}, 1 \%$ Triton X-100, $1 \%$ sodium deoxycholate, $0.1 \%$ SDS, $1 \mathrm{mM}$ PMSF, $100 \mu \mathrm{g} / \mathrm{ml}$ leupeptin, $100 \mu \mathrm{g} / \mathrm{ml}$ pepstatin, $100 \mathrm{KJE} / \mathrm{ml}$ aprotinin, $30 \mathrm{mM}$ Hepes, $\mathrm{pH} 7.3$, and left on ice for $30 \mathrm{~min}$. Insoluble material was pelleted by centrifugation 220,000 $\mathrm{g}$ for $12 \mathrm{~min}$ in an Airfuge (Beckman Instruments Co., Palo Alto, CA ). The supernatant was incubated for $1 \mathrm{~h}$ at $4^{\circ} \mathrm{C}$ with 20 $\mu \mathrm{l}$ rabbit anti-albumin (A 001; Dakopatts A/S, Glostrup, Denmark), after which $40 \mu$ l Protein A-Sepharose $(50 \mathrm{mg} / \mathrm{ml}$ ) (Pharmacia-LKB) was added. The sample was then rotated end over end for $1 \mathrm{~h}$ after which the Protein A-Sepharose was sedimented by centrifugation and washed three times in RIPA buffer, once in $150 \mathrm{mM} \mathrm{NaCl}, 10 \mathrm{mM}$ Tris pH 6.8, and finally once in $50 \mathrm{mM}$ Tris $\mathrm{pH} 6.8$. The pellet was then resuspended in $50 \mu 1 \mathrm{H}_{2} \mathrm{O}$, mixed with $75 \mu$ l electrophoresis sample buffer, boiled for $5 \mathrm{~min}$, and subjected to SDS-PAGE on a $5-20 \%$ gradient gel under reducing conditions (15). The gels were fixed in $7.5 \%$ acetic acid, $40 \%$ ethanol for $1 \mathrm{~h}$, submerged in Amplify (Amersham International, Amersham, UK) for $1 \mathrm{~h}$, dried, and mounted on Kodak X-Omat $\mathbf{S}$ with an intensifying screen. The films were developed after exposure for $1-2$ wk at $-80^{\circ} \mathrm{C}$.

Subcellular fractionation. Neutrophils were resuspended in KRP buffer containing $5 \mathrm{mM}$ diisopropyl fluorophosphate (Aldrich Chemical Co., Inc., Milwaukee, WI) and kept on ice for $10 \mathrm{~min}$. After centrifugation at $200 \mathrm{~g}$ for $10 \mathrm{~min}$, the cells were resuspended in $13 \mathrm{ml}$ disruption buffer $(100 \mathrm{mM} \mathrm{KCl}, 3 \mathrm{mM} \mathrm{NaCl}, 1 \mathrm{mM} \mathrm{ATPNa}, 3.5 \mathrm{mM}$ $\mathrm{MgCl}_{2}, 10 \mathrm{mM}$ Piperazine $N, N^{\prime}$-bis2 [ethane-sulfonic acid] [Pipes], ${ }^{1}$ $\mathrm{pH} 7.2$ ) containing $0.5 \mathrm{mM}$ PMSF and disrupted by nitrogen cavitation as described (4). Nuclei and intact cells were sedimented by centrifugation at $400 \mathrm{~g}$ for $15 \mathrm{~min}\left(\mathrm{P}_{1}\right)$ and $10 \mathrm{ml}$ of the postnuclear supernatant $\left(S_{1}\right)$ was applied on top of a $28-\mathrm{ml}$ two-layer Percoll density gradient $(1.05 / 1.12 \mathrm{~g} / \mathrm{ml})$ containing $0.5 \mathrm{mM}$ PMSF and centrifuged as described (4). This resulted in generation of four separate regions that could be identified visually. The bottom band ( $\alpha$-band) containing azurophil granules, the intermediate band ( $\beta$-band) containing specific granules, the top band ( $\gamma$-band) containing plasma membranes and secretory vesicles, and the clear supernatant $\left(S_{2}\right)$ containing cytosol.

Azurophil granules were identified by myeloperoxidase (16) that was quantitated by spectral analysis using an absorption coefficient of the 472-nm peak of $75 \mathrm{mM}^{-1} \mathrm{~cm}^{-1}$ (17). Specific granules were identified by vitamin $B_{12}$-binding protein (18), which was measured as described by Gottlieb et al. (19), as detailed in reference 4 .

Plasma membranes were identified by HLA class I, assayed by a mixed ELISA (Melisa) (20), or by alkaline phosphatase measured in the absence of detergent $(8,11)$. Alkaline phosphatase was assayed with $p$-nitrophenyl phosphate (Sigma Chemical Co., St. Louis, MO) as substrate in a $1 \mathrm{mM} \mathrm{MgCl}, 50 \mathrm{mM}$ sodium barbital buffer, $\mathrm{pH} 10.5$ (21). Secretory vesicles were identified by alkaline phosphatase that

1. Abbreviation used in this paper: Pipes, piperazine $N, N^{\prime}$-bis2[ethane-sulfonic acid].

could only be measured in the presence of $0.2 \%$ Triton X-100 (latent alkaline phosphatase $)(8,11)$.

Immunoblotting. Protein was transferred from SDS-polyacrylamide slabs to $0.2-\mu \mathrm{m}$ nitrocellulose filters (Bio-Rad Laboratories, Richmond, CA) essentially as described by Towbin et al. (22), in 192 $\mathrm{mM}$ glycine, $25 \mathrm{mM}$ Tris $\mathrm{pH} \mathrm{8.3,20 \%} \mathrm{(vol/vol)} \mathrm{methanol,} \mathrm{using} \mathrm{a}$ trans-blot vertical system (Bio-Rad Laboratories). After transfer, additional protein binding sites were blocked by incubation in $2 \%$ Tween20 in PBS for 30 min. Primary antibodies were applied in PBS containing $0.05 \%$ Tween and recognized by peroxidase-conjugated swine antirabbit antibody (P217 Dakopatts). The nitrocellulose filters were

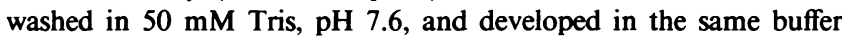
containing $10 \mathrm{mg} / \mathrm{ml}$ DAB-chromogen (Dakopatts) and $0.03 \% \mathrm{H}_{2} \mathrm{O}_{2}$.

$R N A$ extraction and Northern blotting. Human liver tissue was obtained from autopsies and stored at $-80^{\circ} \mathrm{C}$ until RNA extraction. RNA was extracted from liver and leukocytes by the single-step acid guanidinium thiocyanate-phenol-chloroform method (23). The concentration of RNA was determined by spectrophotometry. RNA samples were electrophoresed through a denaturing $1 \%$ agarose gel containing 2.2 $\mathrm{M}$ formaldehyde and transferred to a nylon membrane (GeneScreen Plus; NEN DuPont) in 10X standard saline citrate (SSC) (1X SSC is $150 \mathrm{mM}$ sodium chloride and $15 \mathrm{mM}$ sodium citrate). Radiolabeled probes were prepared by the random priming method (24) using $\left[\alpha-{ }^{32} \mathrm{P}\right] \mathrm{dCTP}$ and a commercial kit (both from Amersham International). The human serum albumin (HSA) probe was a 1.9-kb EcoRI-HindIII cDNA fragment of the cloned human albumin gene (25) containing the entire coding sequence of human albumin, and the human $\beta$-actin probe was a 2.1-BamHI fragment of the plasmid pHF $\beta A-1$ (26). Membranes were prehybridized at $42^{\circ} \mathrm{C}$ in $50 \%$ formamide, $1 \% \mathrm{SDS}, 1 \mathrm{M} \mathrm{NaCl}, 5 \%$ dextran sulfate, and $100 \mu \mathrm{g} / \mathrm{ml}$ denatured salmon testes DNA, and hybridized to the denatured probes for $18-20 \mathrm{~h}$ in the same buffer. Maximal washing stringency was $65^{\circ} \mathrm{C}$ in $2 \times$ SSC, $1 \%$ SDS for $1 \mathrm{~h}$. Membranes were exposed to $x$-ray film at $-80^{\circ} \mathrm{C}$ with an intensifying screen for $1-3 \mathrm{~d}$.

Purification of $67-k D$ protein. Neutrophils were isolated as described above from $10 \mathrm{U}$ of freshly prepared buffy coats and resuspended in KRP at a concentration of $3 \times 10^{7}$ cells $/ \mathrm{ml}$ at $37^{\circ} \mathrm{C}$ on a shaking waterbath. After $5 \mathrm{~min}, 10^{-8} \mathrm{M}$ FMLP was added from a 1 $\mathrm{mM}$ stock in ethanol. After additional $15 \mathrm{~min}$, the cells were pelleted by centrifugation and the supernatant was lyophilized after dialysis against $\mathrm{H}_{2} \mathrm{O}$ and centrifugation at $10,000 \mathrm{~g}$ for $10 \mathrm{~min}$. The material was resuspended in $10 \mathrm{ml} 16.5 \%$ polyethylene glycol 6000 (E. Merck, Darmstadt, Germany), 5 mM Pipes, pH 7.0, and rotated end over end for $1 \mathrm{~h}$ at $4^{\circ} \mathrm{C}$. The precipitate was collected by centrifugation at 10,000 $g$ for $10 \mathrm{~min}$ and the supernatant, enriched in $67-\mathrm{kD}$ protein, was
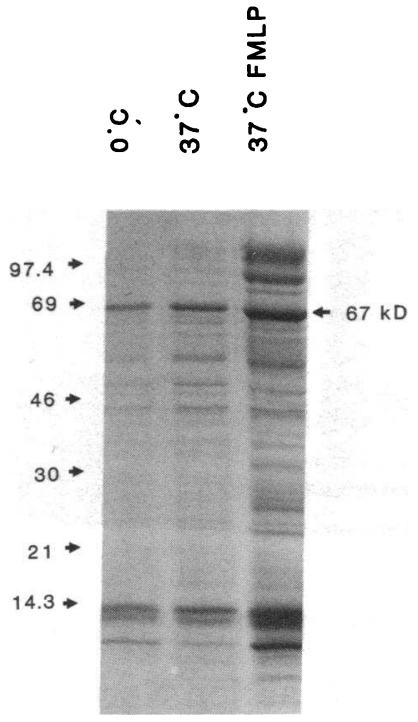

Figure 1. SDS-PAGE protein profile of material exocytosed in response to FMLP stimulation Neutrophils, $3 \times 10^{7}$ cells $/ \mathrm{ml}$, were incubated in $11 \mathrm{ml} \mathrm{KRP}$ at $0^{\circ} \mathrm{C}$ or at $37^{\circ} \mathrm{C}$ in the absence or presence of $10^{-8} \mathrm{M}$ FMLP. After $15 \mathrm{~min}$, the cells were sedimented by centrifugation and the supernatants, $\mathrm{S}_{0}$, were dialyzed against $\mathrm{H}_{2} \mathrm{O}$ and concentrated by Speed-Vac to $0.5 \mathrm{ml}$. $50 \mu \mathrm{l}$ of each supernatant was electrophoresed under reducing conditions on a $5-20 \%$ SDS-polyacrylamide gel with a $3 \%$ stacking gel 
dialyzed overnight against $10 \mathrm{mM}$ Tris, $\mathrm{pH} 9.0$, and applied to a DE 52 column (Whatman International, Ltd., Maidstone, England) equilibrated in $10 \mathrm{mM}$ Tris, $\mathrm{pH} 9.0$ (bed vol $2.5 \mathrm{ml}$ ). The column was

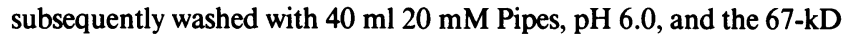
protein and a $92-\mathrm{kD}$ protein were eluted with $150 \mathrm{mM} \mathrm{NaCl}, 20 \mathrm{mM}$ Tris, $\mathrm{pH}$ 7.0. $2 \mathrm{ml}$-containing peak amounts of $67 \mathrm{kD}$ protein as assessed by SDS-PAGE was applied to a Sephadex G-150 (PharmaciaLKB) column (bed vol $300 \mathrm{ml}$ ) equilibrated in $10 \mathrm{mM}$ Tris, $50 \mathrm{mM}$ $\mathrm{NaCl}, \mathrm{pH} 7.0$ (flow rate $6 \mathrm{ml} / \mathrm{h}$ ). Fractions containing peak amounts of $67 \mathrm{kD}$ protein $(\sim 0.5 \mathrm{mg})$ were pooled, dialyzed against $\mathrm{H}_{2} \mathrm{O}$, lyophilized, and processed for $\mathrm{NH}_{2}$-terminal amino acid sequencing.

Protein was determined using a kit (Bio-Rad Laboratories).

Sequence analysis. The amino acid sequence of the purified protein was determined using an automatic protein sequencer (475A; Applied Biosystems, Inc., Foster City, CA) equipped with an on-line HPLC system for detection of the amino acid phenylthiohydanthoin (PTH) derivatives. The PTH-derivatives were separated on a C18-DB column (5-7943; Supelco Inc., Supelco Park, PA). All chemicals and solvents were sequence- or HPLC-grade delivered by Applied Biosystems, Inc.

Amino acid analysis. The purified protein was hydrolyzed for $20 \mathrm{~h}$ in $6 \mathrm{~N} \mathrm{HCl}$ gas phase at $110^{\circ} \mathrm{C}$ under vacuum in pyrolyzed tapered microvials ( $100 \mu \mathrm{l}$; Hewlett-Packard Co., Waldbronn, Germany). The hydrolysate was dried and redissolved in $8 \mu \mathrm{l}$ of $0.4 \mathrm{M}$ sodium borate, $\mathrm{pH}$ 10.4. Amino acid analysis was performed on $6 \mu \mathrm{l}$ using a Aminoquant analyzer (Hewlett-Packard Co.) (27) (precolumn derivatization with $o$-phthaldialdehyde followed by 9-fluorenylmethylchloroformate, both reagents supplied by Hewlett-Packard Co.).

ELISA. Albumin was quantitated by an ELISA using a rabbit polyclonal antibody for catching (Dakopatts A 001) diluted 1:5,000 in 50 $\mathrm{mM} \mathrm{Na} \mathrm{CO}_{3} / \mathrm{NaHCO}_{3}$, pH 9.6. $100 \mu \mathrm{l}$ was applied in each well (96 wells immunoplates; Nunc, Roskilde, Denmark) and incubated at room temperature overnight. The wells were washed in buffer $\mathrm{A}$ ( 500 $\mathrm{mM} \mathrm{NaCl}, 3 \mathrm{mM} \mathrm{KCl}, 8 \mathrm{mM} \mathrm{Na} \mathrm{HPO}_{4} / \mathrm{KH}_{2} \mathrm{PO}_{4}$, pH 7.2, $1 \%$ [vol/ vol] Triton X-100). Additional binding sites were blocked by a 1-h incubation with $200 \mu$ l buffer B $(500 \mathrm{mM} \mathrm{NaCl}, 3 \mathrm{mM} \mathrm{KCl}, 8 \mathrm{mM}$ $\mathrm{Na}_{2} \mathrm{PO}_{4} / \mathrm{KH}_{2} \mathrm{PO}_{4}, \mathrm{pH} 7.2,1 \%$ [vol/vol] Triton X-100, $1 \%$ [wt/vol] BSA [Sigma Chemical Co.]). After washing three times in buffer A, $100 \mu \mathrm{l}$ samples were applied along with serial dilutions of a HSA (Sigma Chemical Co.) standard $(250 \mathrm{ng} / \mathrm{ml})$ and incubated for $1 \mathrm{~h}$. All dilutions of samples and standard were made in buffer B. After three additional washes in buffer $\mathrm{A}, 100 \mu \mathrm{l}$ of affinity purified, biotinylated (see below) rabbit anti-HSA antibody was applied from a stock $(0.12$ $\mathrm{mg} / \mathrm{ml}$ ) diluted $1: 10,000$ in buffer $B$ and incubated for $1 \mathrm{~h}$, followed by washing three times in buffer A. $100 \mu l$ peroxidase-conjugated avidin (Dakopatts P 347) diluted 1:2,000 in buffer B was then added and incubated for $1 \mathrm{~h}$, followed by washing three times in buffer $A$ and once in $100 \mathrm{mM} \mathrm{Na} 2 \mathrm{HPO}_{4} / \mathrm{NaH}_{2} \mathrm{PO}_{4}, 100 \mathrm{mM}$ sodium citrate pH 5.0. Color was developed after $30 \mathrm{~min}$ incubation in sodium phosphate citric acid buffer containing $0.04 \%$ (wt/ vol) $o$-phenylenediamine and $0.03 \% \mathrm{H}_{2} \mathrm{O}_{2}$, and stopped by addition of $100 \mu \mathrm{l} 1 \mathrm{M} \mathrm{H}_{2} \mathrm{SO}_{4}$. Absor-
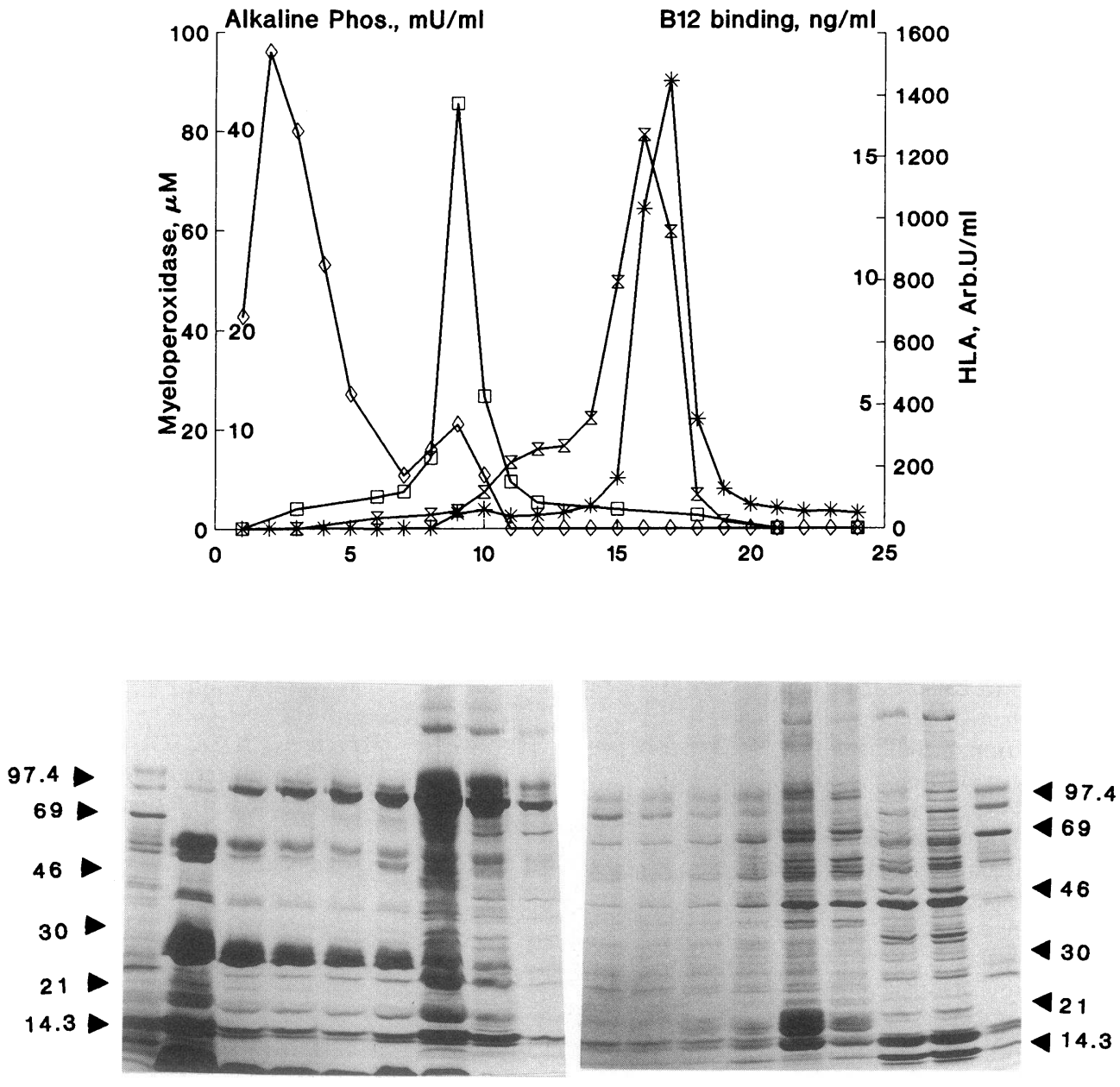

Figure 2. SDS-PAGE protein profile of subcellular fraction of unstimulated neutrophils. 5 $\times 10^{8}$ neutrophils were cavitated in $13 \mathrm{ml}$ disruption buffer. $10 \mathrm{ml}$ of the postnuclear supernatant $S_{1}$ was applied on a 28-ml twolayer Percoll gradient and centrifuged. Fractions of $1.5 \mathrm{ml}$ were collected from the bottom of the gradient. The profile of markers for azurophil granules (myeloperoxidase), specific granules (vitamin $B_{12}$-binding protein), secretory vesicles (latent alkaline phosphatase), and plasma membranes (HLA class I) is given on top. $400 \mu \mathrm{l}$ of each fraction was centrifuged for $20 \mathrm{~min}$ in an Airfuge to pellet the Percoll. The biological material was collected as a disc, resuspended in $100 \mu \mathrm{l}$ saline and mixed with $100 \mu$ l electrophoresis sample buffer. $150 \mu \mathrm{l}$ from each fraction was applied to electrophoresis under reducing conditions in a 5-20\% polyacrylamide slab gel with a $3 \%$ stacking gel (15). Myeloperoxidase, $\diamond$; vitamin $B_{12}$-binding protein, $\square$; latent alkaline phosphatase, $8 ;$ HLA class I, $\star$. 


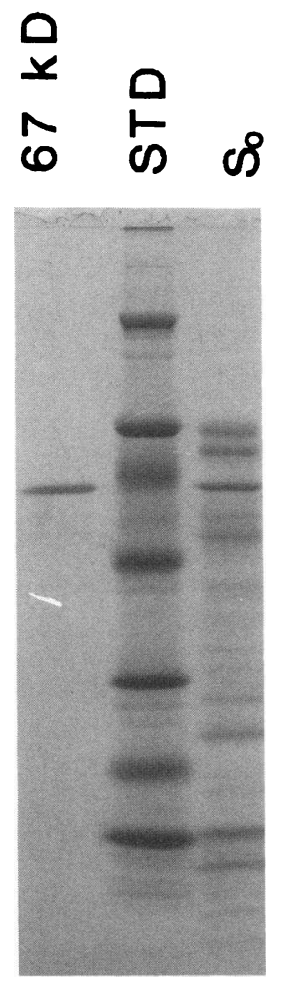

Figure 3. SDS-PAGE of purified $67 \mathrm{kD}$ protein. A 5-20\% SDS polyacrylamide gradient gel was run under reducing conditions with a $3 \%$ stacking gel. (Lane $A$ ) $3 \mu \mathrm{g}$ of $67 \mathrm{kD}$ protein purified from extracellular medium of FMLP-stimulated neutrophils from buffycoat preparations; (Lane $B$ ) Molecular mass standards: $14.3 \mathrm{kD} ; 21 \mathrm{kD} ; 30 \mathrm{kD} ; 46 \mathrm{kD}$; $69 \mathrm{kD} ; 97.4 \mathrm{kD} ; 200 \mathrm{kD}$; (Lane $C$ ) $25 \mu \mathrm{g}$ protein from $\mathrm{S}_{0}$.

bance at $492 \mathrm{~nm}$ was read in a Multiscan Plus automatic ELISA reader (Labsystems, Helsinki, Finland).

Affinity purification and biotinylation. $16 \mathrm{mg}$ rabbit anti-HSA (Dakopatts A 001) was dialyzed overnight in PBS and applied to a CNBractivated Sepharose column (Pharmacia-LKB) to which $4 \mathrm{mg}$ HSA had been coupled according to the manufacturer's instruction. After washing until the eluate displayed background absorbance at $280 \mathrm{~nm}$,

Table I. Amino Acid Analysis of the 67-kD Protein Compared with Human Albumin

\begin{tabular}{ccc} 
& \multicolumn{2}{c}{ Mole \% } \\
\cline { 2 - 3 } Amino acid & $h$-Albumin & 67 kD protein \\
\hline Asx & 9.9 & 9.8 \\
Glx & 15.1 & 15.1 \\
Ser & 4.2 & 4.2 \\
His & 2.9 & 3.1 \\
Gly & 2.2 & 4.1 \\
Thr & 5.3 & 4.8 \\
Ala & 11.5 & 10.4 \\
Arg & 4.0 & 4.8 \\
Tyr & 3.2 & 2.8 \\
Val & 7.1 & 6.8 \\
Met & 1.1 & 1.4 \\
Ile & 1.5 & 1.8 \\
Phe & 5.5 & 5.3 \\
Leu & 11.1 & 10.7 \\
Lys & 10.8 & 10.4 \\
Pro & 4.6 & 4.3 \\
& & \\
\hline
\end{tabular}

The analysis was performed on $6 \mathrm{pmol}$ protein. Mole \% is expressed as $\%$ of all amino acids except Cys and Trp, which were not determined.

* Reference 32.
Table II. Sequence Analysis of the $\mathrm{NH}_{2}$-terminus of the 67-kD Protein Compared with Human Albumin

\begin{tabular}{|c|c|c|c|}
\hline \multirow[b]{2}{*}{ No. } & \multicolumn{3}{|c|}{ Amino acid } \\
\hline & $h$-Albumin* & $67 \mathrm{kDa}$ protein & Net pmol \\
\hline 1 & Asp & $?$ & - \\
\hline 2 & Ala & Ala & 228 \\
\hline 3 & His & His & 75 \\
\hline 4 & Lys & Lys & 258 \\
\hline 5 & Ser & $?$ & - \\
\hline 6 & Glu & Glu & 172 \\
\hline 7 & Val & Val & 224 \\
\hline 8 & Ala & Ala & 242 \\
\hline 9 & His & His & 90 \\
\hline 10 & Arg & Arg & 202 \\
\hline 11 & Phe & Phe & 191 \\
\hline 12 & Lys & Lys & 234 \\
\hline 13 & Asp & Asp & 158 \\
\hline 14 & Leu & Leu & 136 \\
\hline 15 & Gly & Gly & 126 \\
\hline 16 & Glu & Glu & 107 \\
\hline 17 & Glu & Glu & 102 \\
\hline 18 & Asn & Asn & 132 \\
\hline 19 & Phe & Phe & 151 \\
\hline 20 & Lys & Lys & 132 \\
\hline 21 & Ala & Ala & 86 \\
\hline 22 & Leu & Leu & 110 \\
\hline 23 & Val & Val & 102 \\
\hline 24 & Leu & Leu & 74 \\
\hline 25 & Ile & Ile & 116 \\
\hline 26 & Ala & Ala & 142 \\
\hline 27 & Phe & Phe & 126 \\
\hline 28 & Ala & Ala & 135 \\
\hline 29 & Gln & Gln & 101 \\
\hline 30 & Tyr & Tyr & 94 \\
\hline 31 & Leu & Leu & 151 \\
\hline 32 & Gln & Gln & 116 \\
\hline
\end{tabular}

The analysis was performed on 300 pmol protein. Net pmol is the yield of the PTH-derivative corrected for background and lag.

* Reference 32

bound antibodies were eluted with $3 \mathrm{M} \mathrm{KSCN}$ in PBS. The protein peak, judged by $280 \mathrm{~nm}$ absorbance, was collected and dialyzed overnight against PBS for use in immunoelectron microscopy or against $100 \mathrm{mM} \mathrm{Na}_{2} \mathrm{HCO}_{3}, 150 \mathrm{mM} \mathrm{NaCl}$ for biotinylation. Biotinylation was performed essentially as described (28).

Immunofluorescence studies on single cells. Isolated neutrophils were resuspended and fixed at $10^{7}$ cells $/ \mathrm{ml}$ in $2 \%$ paraformaldehyde, $0.1 \%$ glutaraldehyde in PBS for $10 \mathrm{~min}$ at $4^{\circ} \mathrm{C}$. The cells were washed twice in PBS and permeabilized for 20 min with $0.2 \%$ Triton X-100 where appropriate. Fc receptors were blocked by incubating the cells in PBS containing $1 \mathrm{mg} / \mathrm{ml}$ human immunoglobulin (State Serum Institute, Copenhagen) for $1 \mathrm{~h}$ followed by washing. Labeling of cells with monoclonal antibodies was performed by incubating $100 \mu \mathrm{l}$ cells $10^{7} / \mathrm{ml}$ in PBS with $50 \mu \mathrm{l}$ monoclonal antibody or murine preimmune serum for $1 \mathrm{~h}$ at $4^{\circ} \mathrm{C}$. After washing twice in PBS by centrifugation, 50 $\mu l$ fluorescein-conjugated rabbit anti-mouse antibody (Dakopatts) was added and the cells incubated for $30 \mathrm{~min}$ at $4^{\circ} \mathrm{C}$. After two additional washes, the cells were resuspended in PBS and analyzed in a FACScan ${ }^{\otimes}$ (Becton-Dickinson Immunocytometry Sys., Mountain View, CA). 


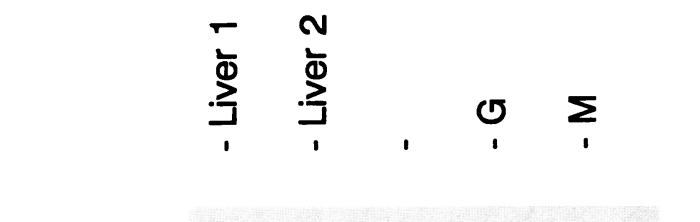

$28 S$ -

$18 S-$

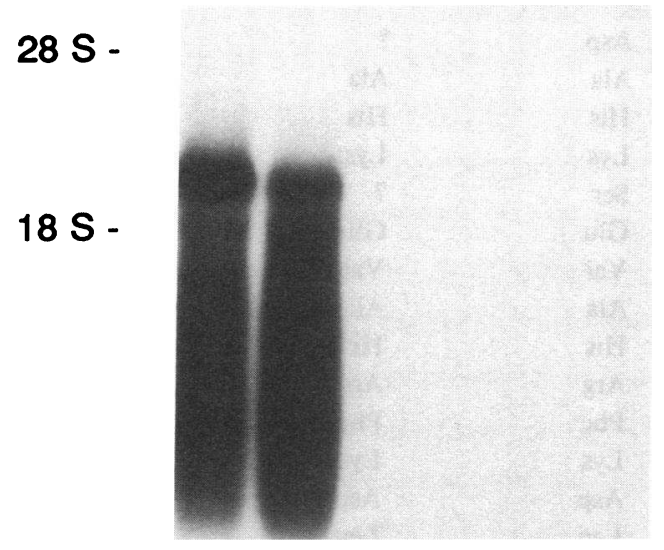

- Albumin

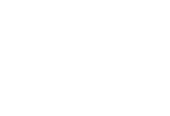

$18 S-$

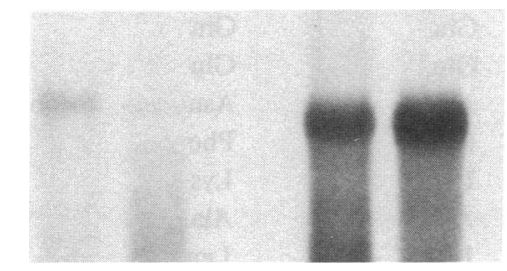

- $\beta$-actin

Figure 4. Northern blotting of albumin mRNA expression in human liver (positive control) and in granulocytes. $15 \mu \mathrm{g}$ of total RNA was loaded per lane. The smearing seen in the liver sample is due to partial degradation of the RNA that was obtained from autopsies. The same blots were stripped and reprobed with a human $\beta$-actin specific probe in order to ascertain the quality of the RNA isolated from the granulocytes. Molecular weight was determined with reference to the 18 and $28 \mathrm{~S}$ rRNA bands. $(G)$ mature granulocytes isolated from bone marrow; $(M)$ mononuclear cells isolated from bone marrow.

Immunostaining of semi- and ultrathin cryosections. Neutrophils, $10^{7}$ cells $/ \mathrm{ml}$, were fixed at $4^{\circ} \mathrm{C}$ in $2 \%$ paraformaldehyde and $0.5 \%$ glutaraldehyde in PBS for $20 \mathrm{~min}$, then washed in $0.1 \mathrm{M}$ phosphate

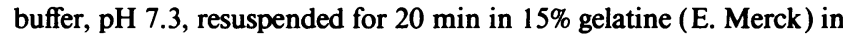
$0.1 \mathrm{M}$ phosphate buffer at $37^{\circ} \mathrm{C}$, and pelleted at $4,100 \mathrm{~g}$ for $2 \mathrm{~min}$. The gelatine was hardened for $18 \mathrm{~h}$ at $4^{\circ} \mathrm{C}$, and blocks $(1 \times 1 \times 1 \mathrm{~mm})$ of the pellet were cryoprotected by immersion for $45 \mathrm{~min}$ in $2.3 \mathrm{M}$ sucrose with $1 \%$ paraformaldehyde in PBS before they were frozen in liquid nitrogen. Semithin and ultrathin cryosections were made on a RMC MT $6000 \mathrm{X}-\mathrm{L}$ and RMC MT 7CR 21 cryo-ultramicrotomes. Semithin sections were collected on glass slides, ultrathin sections on Formvarcoated nickel grids. A two-layer indirect immunostaining procedure was used for light and electron microscopy $(29,30)$. In short, sucrose was removed by washing, and free aldehyde groups were quenched with $0.02 \mathrm{M}$ glycine. Primary antibody used for light microscopy was monoclonal anti-HSA (lot 128 F 4806; Sigma Chemical Co.) diluted $1: 10$, whereas primary antibody for immunoelectron microscopy was affinity-purified rabbit anti-HSA $10 \mu \mathrm{g} / \mathrm{ml}$. Rabbit preimmune serum $(10 \mu \mathrm{g} / \mathrm{ml} \mathrm{IgG})$ was used as control. After $60 \mathrm{~min}$ incubation with primary antibody at room temperature, sections were washed and exposed to secondary antibodies conjugated to colloidal gold for $60 \mathrm{~min}$. For light microscopy goat anti-mouse IgG conjugated to $1 \mathrm{~nm}$ gold (AuroProbe One PRN 470-473; Amersham International) diluted 1:60, and for electron microscopy goat anti-rabbit IgG with $5 \mathrm{~nm}$ gold particles (AuroProbe EM GAR G5, RPN 420; Amersham International) diluted 1:50 were used. The antibodies were diluted in PBS containing $0.8 \%$ BSA, $0.1 \%$ fish skin gelatine (IGSS quality; Amersham International), and $1 \%$ goat serum (State Serum Institute). The sections were washed before and after incubation with antibodies in the same PBS diluent without goat serum. Semithin sections were examined by epipolarized light in an Olympus BH-2 light microscope after silver-enhancement of the gold labels for $25 \mathrm{~min}$ in the dark with a physical developer containing $14.2 \%$ gum arabic, $0.8 \%$ hydrochinone, $2.4 \%$ citric acid monohydride, $2.2 \%$ trisodium citrate dihydrate, and $0.7 \%$ silverlactate (29). Ultrathin sections were contrasted with uranyl acetate in methyl cellulose before they were examined in a JEOL $100 \mathrm{C}$ electron microscope.

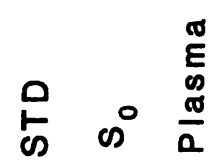

A

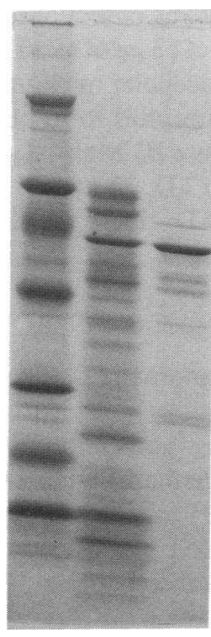

$67 \mathrm{kD}$

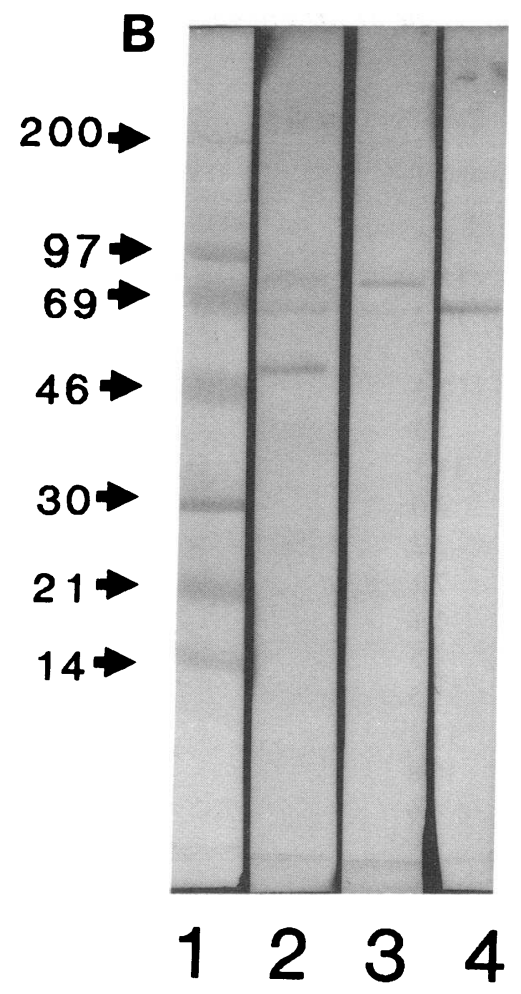

Figure 5. ( $A$ ) SDSPAGE protein profiles of plasma and material exocytosed from neutrophils stimulated by $10^{-8}$ M FMLP. $50 \mu \mathrm{g}$ protein from $\mathrm{S}_{0}$ (same as Fig. 1) and $12.5 \mu \mathrm{g}$ normal human plasma were electrophoresed under reducing conditions on a $5-20 \%$ SDS-polyacrylamide gradient gel with $3 \%$ stacking gel. $(B)$ Western blots of $\mathrm{S}_{0} . \mathrm{S}_{0}$ was transferred from SDSPAGE on 5-20\% gradient gels to nitrocellulose membranes. (Lane 1) MW standards: 14.3 kD; 21 kD; 30 kD; 46 kD; 69 kD; 97.4 kD; $200 \mathrm{kD}$; (lane 2) 2.25 $\mu \mathrm{g}$ protein applied and probed with rabbit antiIgG (Dakopatts A 423); (lane 3) $2.25 \mu \mathrm{g}$ protein applied and probed with rabbit anti-transferrin (Dakopatts A 061); (lane 4) $0.34 \mu \mathrm{g}$ protein applied and probed with rabbit anti-albumin (Dakopatts A001). 

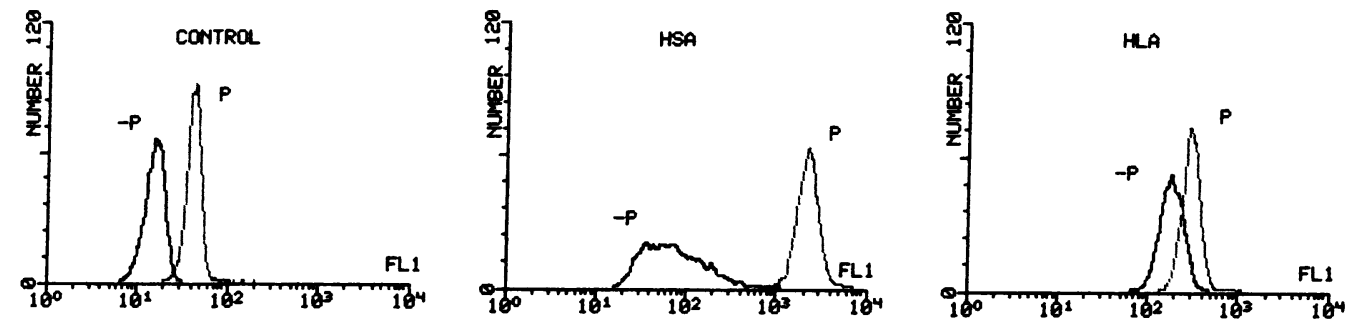

Figure 6. Detection of intracellular albumin by immunofluorescence of single cells. Neutrophils were fixed in $2 \%$ paraformaldehyde, $0.1 \%$ glutaraldehyde. Half the cells $(P)$ were permeabilized with $0.2 \%$ Triton $\mathrm{X}-100$, and the other half $(-P)$ left unpermeabilized. Both were labeled with either murine preimmune IgG (Control) (mouse IgG, diluted 1:49; Becton-Dickinson Immunocytometry), monoclonal anti-human albumin (HSA) (lot 128F-4806 diluted 1:20; Sigma Chemical Co.) or monoclonal anti-HLA (M736 diluted 1:20; Dakopatts A001). Panels are histograms with log fluorescence on abscissa and cell number on ordinate. Mean fluorescence values: (Control $-P) 16 ;($ Control $P) 42 ;(H S A-P) 99 ;(H S A P)$ 2212; (HLA - P) 204; (HLA P) 341.

Quantitation of FITC-Dextran. Fluorescence of FITC-Dextran 70 (Sigma Chemical Co.) was measured in a Scanning Fluorescence spectrophotometer ( F-4000, excitation $485 \mathrm{~nm}$, emission $515 \mathrm{~nm}$; Hitachi Ltd., Tokyo, Japan).

\section{Results}

Proteins released by FMLP stimulation. The protein profile of concentrated extracellular medium $\left(S_{0}\right)$ from control cells and FMLP-stimulated cells is shown in Fig. 1. It is apparent that a variety of different proteins are secreted by merely incubating the cells at $37^{\circ} \mathrm{C}$, but much more is released after stimulation by FMLP. Some of these proteins may be released from their membrane anchor, e.g., Fc-receptor III (31), others exocytosed from intracellular stores, such as secretory vesicles and specific granules. To discriminate between these possibilities, subcellular fractionation of unstimulated cells was performed to localize the source of exocytosed proteins. The SDS-PAGE profile (Fig. 2) indicated that a $67-\mathrm{kD}$ protein qualify as a potential marker for secretory vesicles by the criteria that the protein should be present in fractions of unstimulated neutrophils known to contain latent alkaline phosphatase, the protein should not be present in significant amounts in specific or azurophil granules, and the protein should be a prominent band in $S_{0}$ from FMLP-stimulated neutrophils (Fig. 1).

Identification of the $67-k D$ protein. The $67-\mathrm{kD}$ protein was purified to apparent homogeneity from $\mathrm{S}_{0}$ from FMLP-stimulated neutrophils, as shown in Fig. 3. Briefly, concentrated $S_{0}$ was precipitated by $16.5 \%$ polyethylene glycol. The supernatant that contained the majority of the $67-\mathrm{kD}$ protein together with minor small molecular weight proteins and a prominent 92-kD protein was applied to anion exchange chromatography (DE 52) and eluted in $150 \mathrm{mM} \mathrm{NaCl}, 20 \mathrm{mM}$ Tris, $\mathrm{pH}$ 7.0. The eluate contained two major bands of 67 and $92 \mathrm{kD}$. These were separated on Sephadex G-150. The sequence of the first 32 $\mathrm{NH}_{2}$-terminal amino acids of the purified protein was determined, and analysis of the amino acid composition was performed. As shown in Table I and II, the $67-\mathrm{kD}$ protein is identical to albumin (32).

Origin of albumin. To determine whether albumin had been taken up from plasma or synthesized, like other granule proteins, a cDNA probe was used to detect mRNA for human albumin in both mononuclear and polymorphonuclear bone marrow cells. No mRNA could be detected, as shown in Fig. 4. Likewise, incubation of mononuclear bone marrow cells with $\left[{ }^{14} \mathrm{C}\right]$ leucine did not result in incorporation of radioactivity in albumin when subsequently probed by immunoprecipitation with monoclonal antibody or polyclonal antibodies to human albumin (data not shown). This indicates that albumin is incorporated into neutrophils or their precursors by an endocytic process. To determine whether this is specific for uptake of albumin, we compared the protein profile of plasma and concentrated $\mathrm{S}_{0}$ (Fig. $5 \mathrm{~A}$ ). It is evident that most bands identified in plasma can also be observed in $\mathrm{S}_{0}$. Immunoblotting demonstrated the presence of $\mathrm{IgG}$, transferrin, and albumin in $\mathrm{S}_{0}$ (Fig. $5 B$ ). In addition, $S_{0}$ contains a few prominent bands not ob-

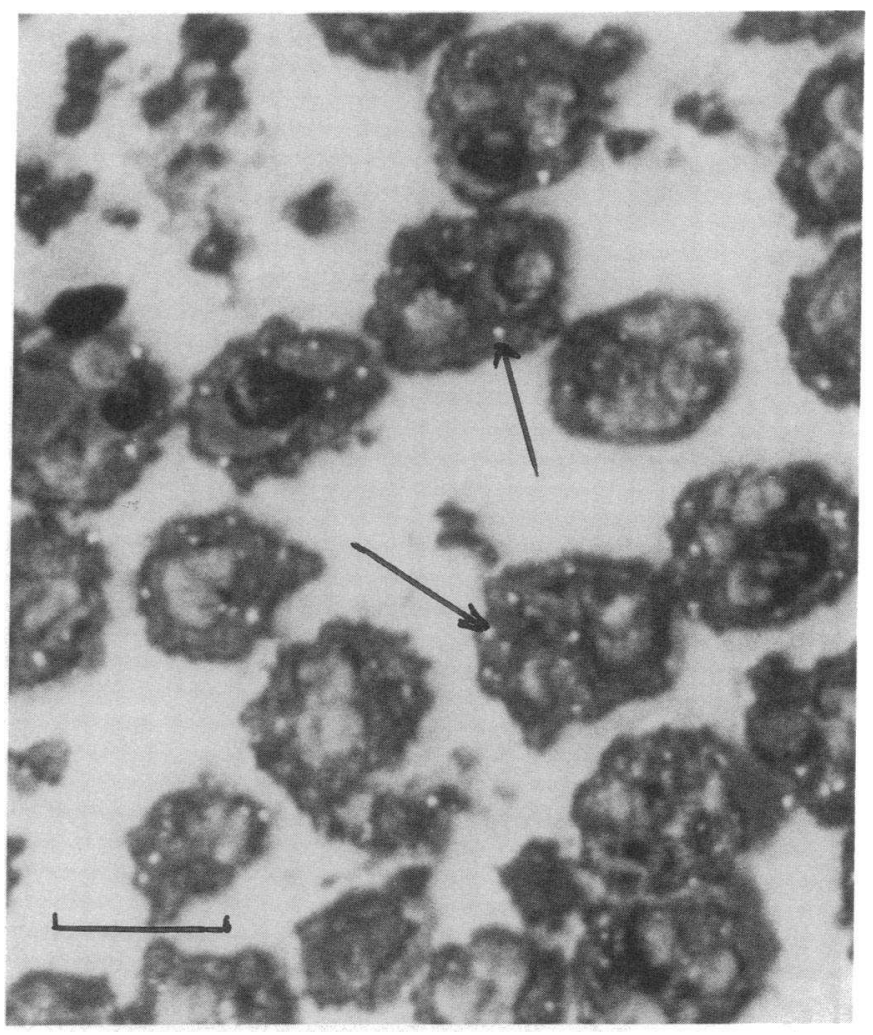

Figure 7. Epipolarized light micrograph of fixed, cryosectioned neutrophils incubated with mouse monoclonal anti-HSA as primary antibody and $1 \mathrm{~nm}$ gold-conjugated rabbit anti-mouse as secondary antibody. The gold labeling was silver enhanced. When viewed in epipolarized light the silver is seen as bright spots. These show that immunolabeling for albumin is confined to granule-like structures scattered in the cytoplasm (arrows). $\times 1,800$. Bar, $10 \mu \mathrm{m}$. 

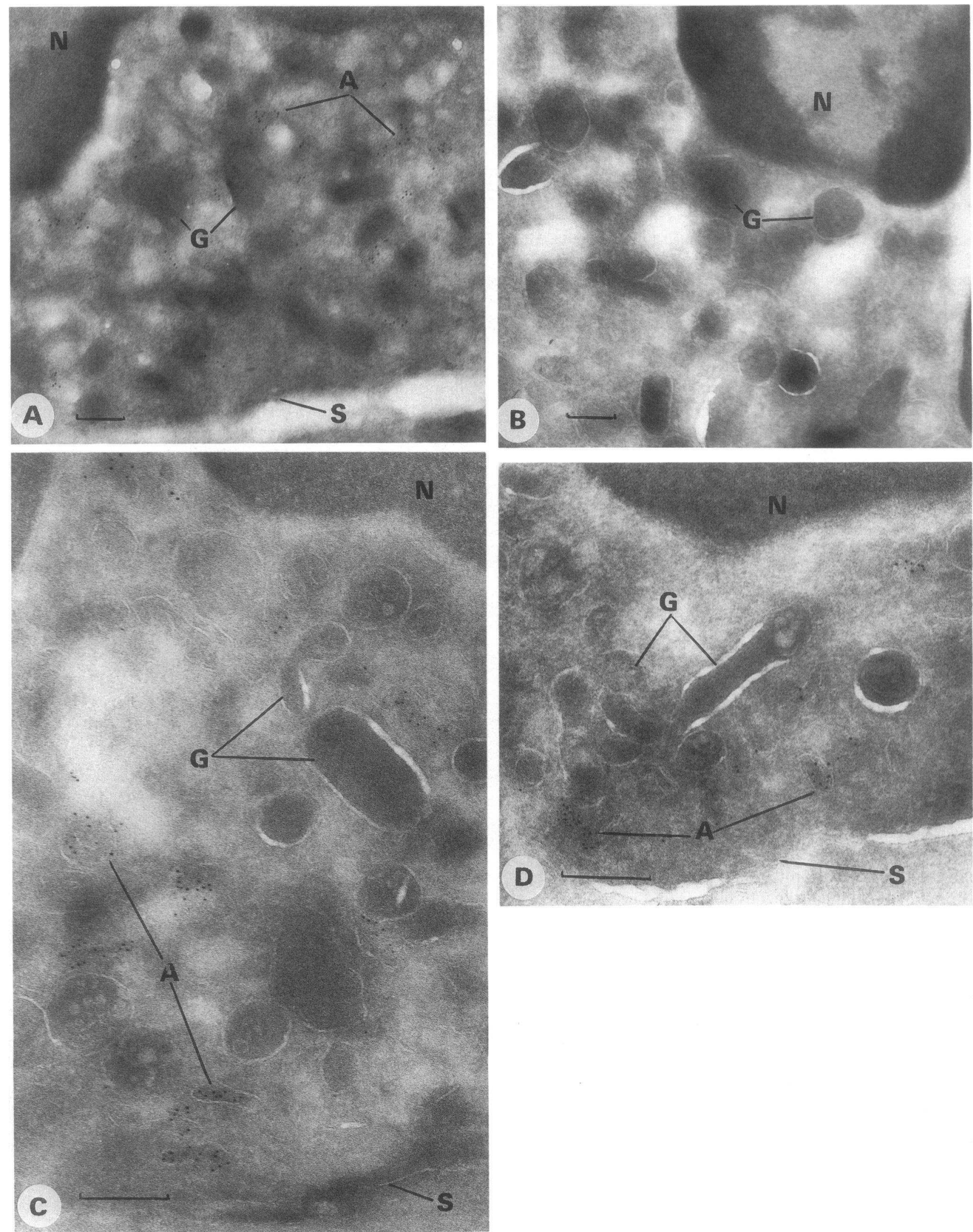

Figure 8. $(A-D)$ Immunogold electron microscopy of fixed ultrathin cryosectioned neutrophils, incubated with affinity-purified rabbit anti-HSA and $5 \mathrm{~nm}$ gold-conjugated anti-rabbit $\operatorname{IgG}(A, C, D)$, or, as control, preimmune rabbit serum before immunogold $(B)$. At lower magnification immunolabeling for albumin $(A)$ is present as clusters of gold particles $(A)$ in the cytoplasm between the neutrophil granules $(G)$. No labeling is observed when preimmune serum is used $(B)$. At higher magnification $(C, D)$ it is evident that albumin labeling $(A)$ is confined to membrane-limited structures distinct from specific and azurophil granules $(G) . N$ denotes the nucleus, $S$ the cell surface membrane. $A, B, \times 34,000$; $C, D, \times 65.000$. Bar, $250 \mathrm{~nm}$. 

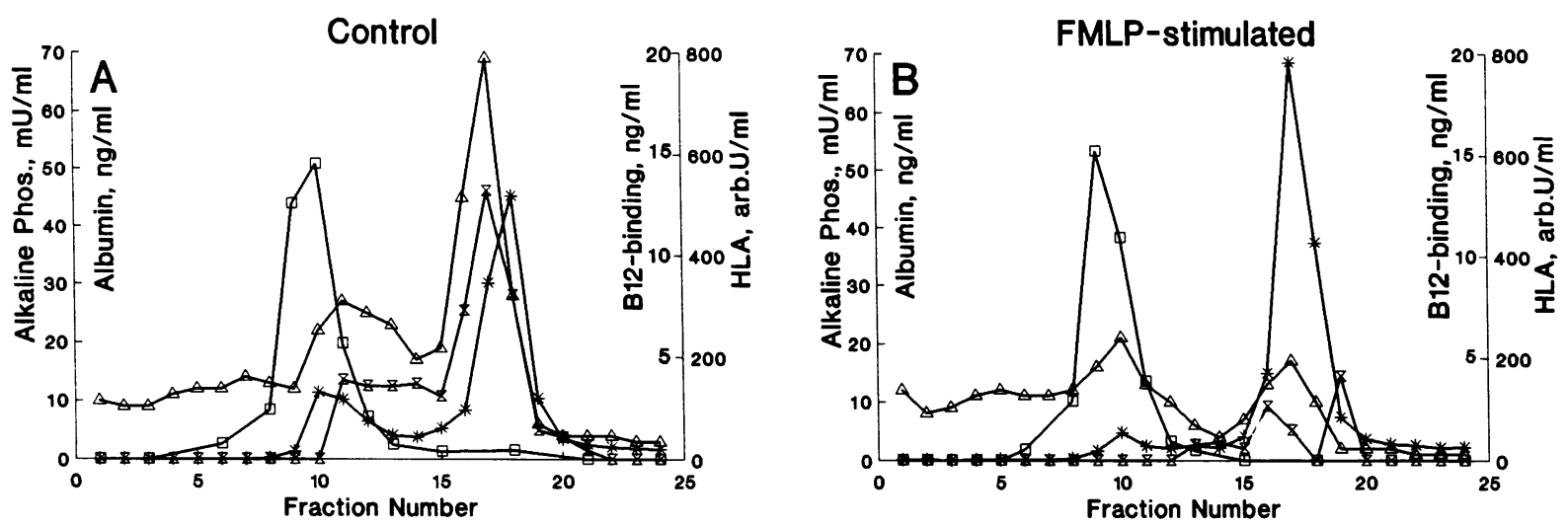

Figure 9. Subcellular localization of albumin in unperturbed and FMLP-stimulated neutrophils. $6 \times 10^{8}$ neutrophils were incubated at $3 \times 10^{7}$ cells $/ \mathrm{ml}$ in KRP. One half was kept at $0^{\circ} \mathrm{C}$, the other half incubated at $37^{\circ} \mathrm{C}$ in the presence of $10^{-8} \mathrm{M} \mathrm{FMLP}$. After 15 min incubation, the cells were pelleted by centrifugation, disrupted by nitrogen cavitation, and fractionated on two-layer Percoll gradients. $A$ is control cells kept at $0^{\circ} \mathrm{C}$. $B$ is FMLP-stimulated cells. Vitamin $B_{12}$-binding protein, $\square$; Latent alkaline phosphatase, 8 ; Albumin, $\triangle$; HLA, $\star$.

served in plasma when comparable amounts of protein are applied. Most of these bands seem to represent proteins from specific granules, as observed in Fig. 2.

Subcellular localization of albumin. Since albumin was the dominating plasma-related protein released in $\mathrm{S}_{0}$ by FMLP treatment, we chose to study the localization and release of albumin in more detail. To verify the intracellular localization of albumin in normal neutrophils, immunofluorescence studies were performed on fixed neutrophils before and after permeabilization. As shown in Fig. 6, permeabilization of neutrophils resulted in increased fluorescence of anti-albumin antibodies, indicating that intracellularly localized antigen was made available to the antibody. As control, no significantly increased fluorescence was observed when an antibody to HLA class I antigen was used as a marker for the plasma membrane. Epipolarized light microscopy of immunogold-silver stained cryosections (Fig. 7) showed labeling for albumin in scattered cytoplasmic granule-like structures with no apparent preference for any part of the cell. Immunoelectron microscopy of ultrathin cryosections (Fig. 8) demonstrated labeling for albumin in distinct intracellular membrane-limited organelles, quite similar to the alkaline phosphatase containing secretory vesicles that have recently been morphologically described (33). This was confirmed by subcellular fractionation of cavitated neutrophils on two-layer Percoll gradients. Fig. 9 shows that the major part of albumin co-localizes with latent alkaline phosphatase and is separate from the plasma membrane marker HLA. Since plasma membrane vesicles and secretory vesicles have very similar density, their peaks are only separated by one fraction. This was, however, invariably observed in all of four experiments of which the experiment in Fig. 9 is typical, and can also be observed in Fig. 2. After stimulation with FMLP, this pool of albumin is exocytosed. It should be noted that although the exocytosis of secretory vesicles and the associated albumin pool is almost complete, only minimal exocytosis of specific granules occurs. This is illustrated by Fig. 10, which gives the release of albumin and the specific granule marker vitamin $B_{12}$-binding protein along with upregulation of alkaline phosphatase in response to a range of concentrations of FMLP, platelet activating factor (PAF), and $\mathrm{LTB}_{4}$.
Endocytosis of FITC-dextran. Unstimulated neutrophils have been reported to take up albumin and FITC-dextran by fluid phase endocytosis to varying degrees (34-36). This process is reported to be accelerated by FMLP stimulation (35). Fig. 11 shows that FMLP stimulation results in increased cell association of FITC-dextran. However, the majority of the FITC-dextran is not sedimented by centrifugation and is found on top of the density gradient that contains cytosol and extracellular buffer. Since FITC-dextran does not enter the cytosol, this indicates that the FITC-dextran, albeit cell associated, is released to the external medium when the cells are disrupted. Thus, the FITC-dextran is either released from phagocytic vacuoles that all break during disruption of cells. This is less likely, since no significant breaking of any other organelle is observed during nitrogen cavitation. Alternatively, the cell-associated FITC-dextran is localized extracellularly, and therefore released when cells are disrupted.

In addition to the FITC-dextran on top of the gradient, a smaller peak of FITC-dextran is associated with more dense structures deep in the gradient. It should be noted that the fluid phase endocytosis marker did not concentrate in fractions either in unstimulated cells or in stimulated cells that contain latent alkaline phosphatase.

\section{Discussion}

Normal neutrophils were shown to contain albumin in intracellular stores that are easily mobilized by weak secretagogues. The fact that small amounts of albumin was released by incubating cells in the absence of stimulus probably reflects the high sensitivity to exocytosis of the albumin-containing vesicles. In this respect, the kinetics of exocytosis of albumin is similar to the kinetics of upregulation of CR-1 and CR-3 in response to isolation and warming of isolated neutrophils ( 7), as also previously noted for secretory vesicles (11). Judged by the protein profile of exocytosed material and by our previous demonstration of similar intracellular localization of another plasma protein, tetranectin (8), albumin seems to be associated with most other plasma proteins. 

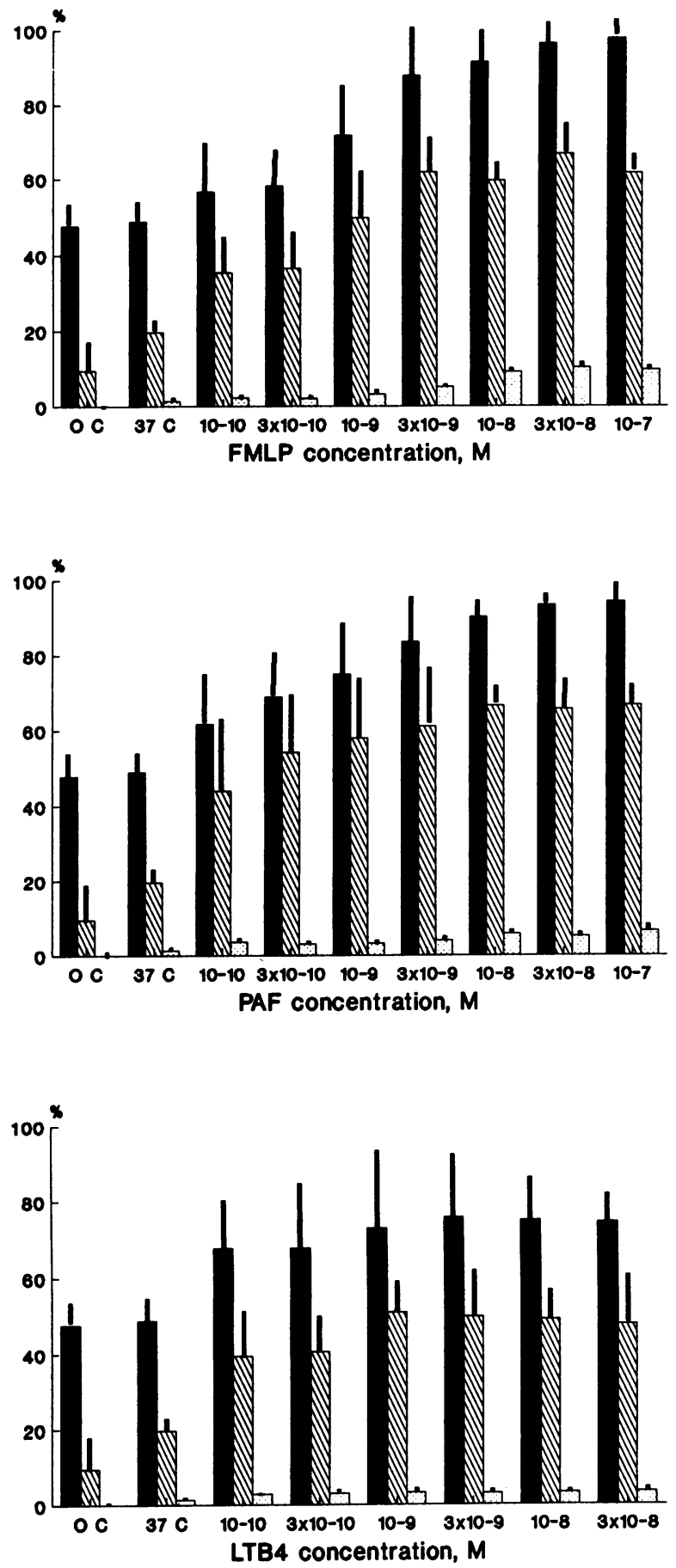

Figure 10. Exocytosis of albumin in response to stimulation with inflammatory mediators. Neutrophils, $3 \times 10^{7} / \mathrm{ml}$ in $\mathrm{KRP}$, were incubated at $37^{\circ} \mathrm{C}$ for $20 \mathrm{~min}$ with additions as indicated. Control cells were incubated either on ice or at $37^{\circ} \mathrm{C}$. The incubation was terminated by adding 2 vol ice-cold KRP. Cells were sedimented by centrifugation $200 \mathrm{~g}$ for $10 \mathrm{~min}$ and resuspended to their original volume. Release was expressed as content in supernatant as percentage of content in resuspended cells plus supernatant. Alkaline phosphatase was measured in the presence and absence of $0.2 \%$ Triton X-100 and expressed as activity in the absence in percentage of activity in the presence of detergent. Results are mean of three independent experiments (standard deviation is given as |). FMLP was added from a $10^{-3} \mathrm{M}$ stock in ethanol. $\mathrm{LTB}_{4}$ (Sigma Chemical Co.) was added from a $10^{-3} \mathrm{M}$ stock in ethanol. PAF (Sigma Chemical Co.) was added from a $10^{-3} \mathrm{M}$ stock in PBS. Closed bar is alkaline phosphatase. Hatched bar is albumin. Stippled bar is vitamin $B_{12}$ binding protein.
Our previous work on secretory vesicles $(8,11,13)$, and the fact that we are able to separate plasma membrane vesicles from secretory vesicles by free-flow electrophoresis (37) fully support that secretory vesicles are intracellular structures that fuse with the plasma membrane after stimulation. The findings that albumin co-localizes with secretory vesicles on subcellular fractionation and is exocytosed in parallel with exocytosis of secretory vesicles strongly indicate that albumin is localized in secretory vesicles. Since biosynthesis of albumin was not demonstrated, the plasma protein must have been taken up by an endocytic process. This points to the endocytic origin of secretory vesicles. It is therefore not surprising that secretory vesicles contain alkaline phosphatase and cytochrome $b_{558}$, and probably several other membrane proteins also found in the plasma membrane $(8,11,13)$. However, the membrane of secretory vesicles does not contain HLA class I antigen (20). Thus, some segregation of membrane proteins must take place during formation of secretory vesicles.

A recent study has shown uptake of albumin into a tubular system and multivesicular bodies in FMLP-stimulated neutrophils. The membrane of these structures was shown to contain CR1 that originated from small intracellular vesicles, distinct from specific and azurophil granules, before stimulation (38). The ultrastructure of secretory vesicles has recently been described as alkaline phosphatase containing intracellular vesicles that fuse into a tubular system that communicates with the plasma membrane after FMLP stimulation (33). It is therefore likely that the fluid phase markers whose uptake has been claimed to be increased by FMLP stimulation, although apparently located in intracellular vesicles, are associated with this tubular system, and therefore still extracellular. Our studies on subcellular localization of FITC-dextran support this notion. It is, furthermore, evident that stimulation with FMLP does not result in generation of endocytic vesicles containing latent alkaline phosphatase. Thus, the stimulated release of serum proteins and exocytosis of secretory vesicles cannot be interpreted as a consequence of an acceleration of a classical endocytosisexocytosis cycle.

The finding in neutrophils of a stimulus-dependent extensive release of vesicles of endocytic origin bears striking similarity to $\alpha$-granules of platelets that contain plasma proteins that are endocytosed by megakaryocytes $(39,40)$. Some endocytic vesicles in neutrophils undoubtedly represent the traditional constitutive pinocytotic communication between the pericellular environment, lysosomes, and Golgi (41). The small part of intracellular albumin not released by FMLP may be located here where we also find the FITC-dextran that can be sedimented by centrifugation (Figs. 9 and 11), but a significant part of endocytic vesicles in human neutrophils, as defined by their content of plasma proteins, represent unique mobilizable secretory vesicles that are lost after stimulation by weak secretagogues, and not regained within the time frame of formation of normal endocytic vesicles (15-45 $\mathrm{min}$ ) (42). It should be noted that no proteolytic modification of albumin could be detected as a consequence of endocytosis.

Important questions to be answered about endocytic secretory vesicles are: when during myelopoiesis are these vesicles formed, in the bone marrow like $\alpha$-granules of platelets or in the circulation? Do secretory vesicles play a role for the egress of mature neutrophils from the bone marrow and/or for margination of neutrophils in blood vessels by regulating the content of adhesion proteins in the plasma membrane? Has the 
Control

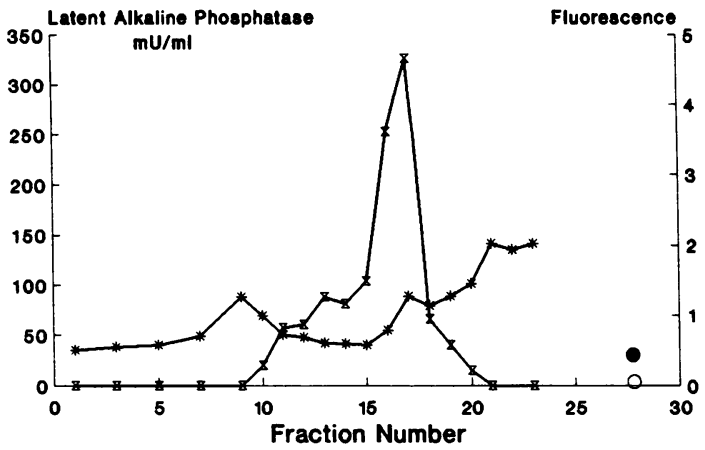

FMLP-Stimulated

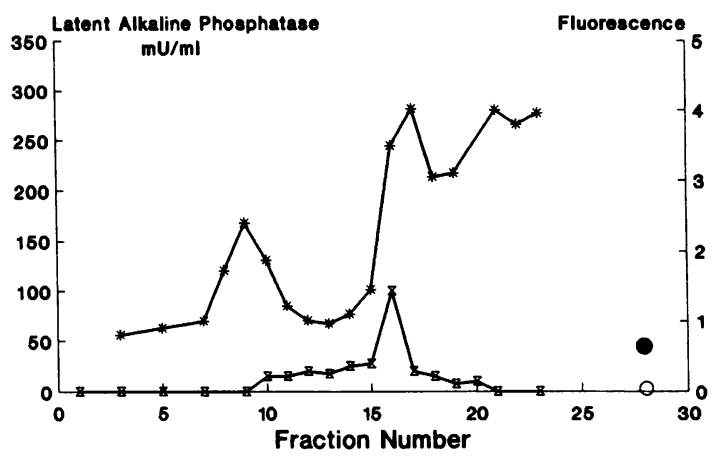

Figure 11. Subcellular localization of cell-associated FITC-dextran. $1.4 \times 10^{9}$ neutrophils were incubated at $5 \times 10^{7} \mathrm{cells} / \mathrm{ml}$ in $\mathrm{KRP}$ at $37^{\circ} \mathrm{C}$ in the presence of $5 \mathrm{mg} / \mathrm{ml}$ FITC-dextran. After $5 \mathrm{~min}$ the sample was divided, $10^{-8} \mathrm{M}$ FMLP (Sigma Chemical Co.) was added to one half, the other served as control. After additional $15 \mathrm{~min}$ the incubation was stopped by dilution with 2 vol ice-cold $\mathrm{KRP}$ and the cells pelleted by centrifugation. The supernatants were siphoned off and the pellets resuspended in $10 \mathrm{ml}$ ice-cold KRP. This was repeated four times. The pellets were finally resuspended in $13 \mathrm{ml}$ relaxation buffer and subjected to subcellular fractionation. Each fraction was analyzed for alkaline phosphatase in the presence or absence of $0.2 \%$ Triton X-100. The difference is given as latent alkaline phosphatase $8 ; 500 \mu \mathrm{l}$ was removed from each fraction, $0.2 \%$ Triton X-100 was added, and Percoll was removed by centrifugation 150,000 g for $20 \mathrm{~min}$ in an Air-fuge (Beckman Instrs.). The supernants were diluted with 2 vol PBS and fluorescence activity measured (arb. units): $(*)$ Fluorescence of relaxation buffer containing $0.2 \%$ Triton X-100 diluted with 2 vol PBS; (O) Fluorescence of supernatant from the last wash before cavitation diluted with 2 vol PBS containing $0.13 \%$ Triton X-100; ( $)$ Results of one of two essentially similar experiments are shown.

existence of stimulus-dependent mobilizable endocytic vesicles been overlooked in other cells, like fibroblasts, endothelial cells, and macrophages? The fact that the plasma protein tetranectin has been demonstrated in all such cells (12) indicates that this may be the case.

\section{Acknowledgments}

The expert technical assistance of Mrs. Charlotte Horn is greatly appreciated. Niels Tygstrup, M.D., Ph.D. Dept of Medicine, A. University Hospital, Copenhagen kindly provided the cDNA for human albumin.

This work was supported by grants from Anders Hasselbalchs Fund, the Gangsted Fund, Emil C. Hertz' Fund, Amalie Jørgensens Fund, Leo Nielsens Fund, Lundbecks Fund, Novo-Nordisk Fund, P. Carl Petersens Fund, the Danish Medical Association, The Danish Medical Research Council, the Fund for the Advancement of Medical Sciences, and Skovgaards Fund. N. Borregaard is the recipient of a Neye Research Professorship.

\section{References}

1. Bainton, D. F., J. L. Ullyot, and M. E. Farquar. 1971. The development of neutrophilic polymorphonuclear leukocytes in human bone marrow. Origin and content of specific and azurophil granules. J. Exp. Med. 143:907-934.

2. Jesaitis, A. J., J. R. Naemura, R. G. Painter, L. A. Sklar, and C. G. Cochrane. 1982. Intracellular localization of $N$-formyl chemotactic receptor and $\mathrm{Mg}^{2+}$-dependent ATP-ase in human granulocytes. Biochim. Biophys. Acta. 719:556-568.

3. Bainton, D. F., L. J. Miller, T. K. Kishimoto, and T. A. Springer. 1987. Leukocyte adhesion receptors are stored in peroxidase-negative granules of human neutrophils. J. Exp. Med. 166:1641-1653.

4. Borregaard, N., J. M. Heiple, E. R. Simons, and R. A. Clark. 1983. Subcellular localization of the $b$-cytochrome component of the human neutrophil microbicidal oxidase. Translocation during activation. J. Cell Biol. 97:53-61.

5. Jesaitis, A. J., E. S. Buescher, D. Harrison, M. T. Quinn, C. A. Parkos, S Livesey, and J. Linner. 1990. Ultrastructural localization of cytochrome $b$ in the membranes of resting and phagocytosing human granulocytes. J. Clin. Invest 85:821-835.

6. Miller, L. J., D. F. Bainton, N. Borregaard, and T. A. Springer. 1987. Stimulated mobilization of monocyte Mac-1 and p 150,95 adhesion proteins from an intracellular vesicular compartment to the cell surface. J. Clin. Invest. 80:535-544.
7. Berger, M., and M. E. Medof. 1987. Increased expression of complement decay-accelerating factor of human neutrophils. J. Clin. Invest. 79:214-220.

8. Borregaard, N., L. Christensen, O. W. Bjerrum, H. S. Birgens, and I. Clemmensen. 1990. Identification of a highly mobilizable subset of human neutrophil intracellular vesicles that contains tetranectin and latent alkaline phosphatase. $J$. Clin. Invest. 85:408-416.

9. Dewald, B., U. Bretz, and M. Baggiolini. 1982. Release of gelatinase from a novel secretory compartment of human neutrophils. J. Clin. Invest. 70:518-525

10. Hibbs, M. S., and D. F. Bainton. 1989. Human neutrophil gelatinase is a component of specific granules. J. Clin. Invest. 84:1395-1402.

11. Borregaard, N., L. J. Miller, and T. A. Springer. 1987. Chemoattractantregulated mobilization of a novel intracellular compartment in human neutrophils. Science (Wash. DC). 237:1204-1206.

12. Christensen, L., and I. Clemmensen. 1989. Tetranectin in normal human tissues: an immunohistochemical study of exocrine epithelia and mesenchyma. Histochemistry. 92:29-35.

13. Bjerrum, O. W., and N. Borregaard. 1989. Dual granule localization of the dormant NADPH oxidase and cytochrome $b_{559}$ in human neutrophils. Eur. $J$. Haematol. 43:67-77.

14. Boyum, A. 1968. Separation of leukocytes from blood and bone marrow. Scand. J. Clin. Lab. Invest. 21 (Suppl.):77-89.

15. Laemmli, U. K. 1970. Cleavage of structural proteins during the assembly of the head of bacteriophage $\mathrm{T}_{4}$. Nature (Lond.). 227:680-695.

16. Spitznagel, J. K., F. G. Dalldorf, M. S. Leffell, J. D. Folds, I. R. H. Welsh, M. H. Cooney, and L. E. Martin. 1974. Character of azurophil and specific granules purified from human polymorphonuclear leukocytes. Lab. Invest. 30:774-785.

17. Bos, A., R. Wever, and D. Roos. 1978. Characterization and quantification of the peroxidase in human neutrophils. Biochim. Biophys. Acta. 525:37-44.

18. Kane, S. P., and T. J. Peters. 1975. Analytical subcellular fractionation of human granulocytes with reference to the localization of vitamin $\mathbf{B}_{12}$-binding protein. Clin. Sci. Mol. Med. 49:171-182.

19. Gottlieb, C., K.-S. Lau, R. L. Wasserman, and V. Herbert. 1965. Rapid charcoal assay for intrinsic factor (IF), gastric juice unsaturated $B_{12}$ binding capacity, antibody to IF, and serum unsaturated $\mathrm{B}_{12}$ binding capacity. Blood. 25:875-893.

20. Bjerrum, O. W., and N. Borregaard. 1990. Mixed enzyme-linked immunosorbent assay (melisa) for HLA class I antigen: a plasma membrane marker. Scand. J. Immunol. 31:305-313.

21. DeChatelet, L. R., and M. R. Cooper. 1970. A modified procedure for the determination of leukocyte alkaline phosphatase. Biochem. Med. 4:61-68.

22. Towbin, H., T. Staehelin, and J. Gordon. 1979. Electrophoretic transfer of proteins from polyacrylamide gels to nitrocellulose sheets: procedure and some applications. Proc. Natl. Acad. Sci. USA. 76:4350-4354.

23. Chomczynski, P., and N. Sacchi. 1987. Single-step method of RNA isolation by acid guanidinium thiocyanate-phenol-chloroform extraction. Anal. Biochem. 162:156-159. 
24. Feinberg, A. P., and B. Vogelstein. 1983. A technique for radiolabeling DNA restriction endonuclease fragments to high specific activity. Anal. Biochem. 132:6-13.

25. Lawn, R. M., J. Adelman, S. C. Bock, A. E. Franke, C. M. Houck, R. C. Najarian, P. H. Seeburg, and K. L. Wion. 1981. The sequence of human serum albumin cDNA and its expression in E. coli. Nucleic Acids Res. 9:6103-6114.

26. Gunning, P., P. Ponte, H. Okayama, J. Engel, H. Blau, and L. Kedes. 1983. Isolation and characterization of full-length cDNA clones from human $\alpha$-, $\beta$ - and $\gamma$-actin mRNAs: skeletal but not cytoplasmic actins have an amino-terminal cysteine that is subsequently removed. Mol. Cell. Biol. 3:787-795.

27. Shuster, R. 1988. Determination of amino acids in biological, pharmaceutical, plant, and food samples by automated precolumn derivatization and highperformance liquid chromatography. J. Chromatogr. 431:271-284.

28. Wilchek, M., and E. A. Bayer. 1990. Avidin-biotin technology. Methods Enzymol. 184:123-166.

29. Bastholm, L., L. Scopsi, and M. H. Nielsen. 1986. Silver-enhanced immunogold staining of semithin and ultrathin cryosections. J. Electron Microsc. 4:175-176.

30. Bastholm, L., M. H. Nielsen, and L.-I. Larsson. 1987. Simultaneous demonstration of two antigens in ultrathin cryosections by a novel application of an immunogold staining method using primary antibodies from the same species. Histochemistry. 87:229-231.

31. Huizinga, T. W. J., M. de Haas, M. Kleijer, J. H. Nuijens, D. Roos, and A. E. G. Kr. von den Borne. 1990. Soluble Fc $\gamma$ receptor III in human plasma originates from release by neutrophils. J. Clin. Invest. 86:416-423.

32. Dayhoff, M. O. 1976. Atlas of Protein Sequences and Structures. Vol. 5, Suppl. 2. National Biomedical Research Foundation, Georgetown University, Washington, DC.

33. Kobayashi, T., and J. M. Robinson. 1991. A novel intracellular compart- ment with unusual secretory properties in human neutrophils. J. Cell Biol. 113:743-756.

34. Cannarozzi, N. A., and S. E. Malawista. 1973. Phagocytosis by human blood leukocytes measured by the uptake of ${ }^{131} \mathrm{I}$-labeled human serum albumin: inhibitory and stimulatory effects of cytochalasin B. Yale J. Biol. Med. 46:177189.

35. Davis, B. H., R. J. Walter, C. B. Pearson, E. L. Becker, and J. M. Oliver. 1982. Membrane activity and topography of f-Met-Leu-Phe-treated polymorphonuclear leukocytes. Am. J. Pathol. 108:206-216.

36. Keller, H. U. 1990. Diacylglycerols and PMA are particularly effective stimulators of fluid pinocytosis in human neutrophils. J. Cell. Physiol. 145:465471.

37. Sengeløv, H., M. H. Nielsen, and N. Borregaard. 1992. Separation of human neutrophil plasma membrane from intracellular vesicles containing alkaline phosphatase and NADPH oxidase activity by free-flow electrophoresis. $J$. Biol. Chem. In press.

38. Berger, M., E. M. Wetzler, E. Welter, J. R. Turner, and A. M. Tartakoff. 1991. Intracellular sites for storage and recycling of $\mathbf{C} 3 \mathrm{~b}$ receptors in human neutrophils. Proc. Natl. Acad. Sci. USA. 88:3019-3023.

39. Handagama, P. J., P. E. Stenberg, R. P. McEver, M. A. Shuman, and D. F. Bainton. 1987. Incorporation of a circulating protein into megakaryocytes and platelet granules. Proc. Natl. Acad. Sci. USA. 80:4045-4049.

40. Handagama, P. J., M. A. Shuman, and D. F. Bainton. 1989. Incorporation of intravenously injected albumin, immunoglobulin $\mathbf{G}$, and fibrinogen in guinea pig megakaryocyte granules. J. Clin. Invest. 84:73-82.

41. van Deurs, B., O. W. Petersen, S. Olsnes, and K. Sandvig. 1989. The ways of endocytosis. Int. Rev. Cytol. 117:131-177.

42. Steinman, R. M., I. S. Mellman, W. A. Muller, and Z. A. Cohn. 1983. Endocytosis and the recycling of plasma membrane. J. Cell Biol. 96:1-27. 